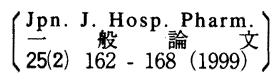

\title{
Enzyme Immunoassay for Secretin-like Immunoreactive Substance in Human Plasma
}

\author{
HIROKI ITOH*, TOSHIAKI NAGANO, TETSUJI HAYASHI \\ and MASAHARU TAKEYAMA \\ Department of Clinical Pharmacy, Oita Medical University $\dagger$
}

\author{
$\left(\begin{array}{l}\text { Received July 3, } 1998 \\ \text { Accepted January 6, } 1999\end{array}\right)$
}

\begin{abstract}
A sensitive and specific enzyme immunoassay (EIA) for a secretin-like immunoreactive substance (secretin-IS) was developed using a synthetic carboxy-terminal (C-terminal) fragment (residue 5-27) of a porcine secretin conjugated with $\beta$-D-galactosidase and an anti-rabbit $\operatorname{lgG}$ coated immunoplate. The activity of the enzyme on the plate was fluorometrically determined. The present immunoassay allows the detection of 1.7 to $67 \mathrm{fmol} / \mathrm{ml}(0.068$ to $2.7 \mathrm{fmol} /$ well $)$ of secretin. Using the present EIA, the secretin-ISs in human plasma were determined.

Moreover, significant changes in the plasma secretin-IS Ievels were found after the oral administration of famotidine (vs.placebo).
\end{abstract}

Key words — secretin, enzyme immunoassay, human plasma, famotidine, secretin (5-27)- $\beta$ D-galactosidase, fluorescence

\section{Introduction}

Secretin was first isolated from porcine small intestine by Jorpes and Mutt ${ }^{1}$. This 27-amino-acid polypeptide has stimulation of pancreatic secretion, inhibition of gastric acid secretion and a stimulating factor that could be carried by the blood to the pancreas to elicit pancreatic secretory response $^{2)}$. At present, the structures of porcine ${ }^{3)}$, bovine ${ }^{4)}$, human ${ }^{5)}$, rat $^{6)}$ and chicken ${ }^{7)}$ secretins are known. Especially, human secretin was found to differ from porcine secretin by two amino acid substitutions at position 15 and 16. Secretin is connected with inhibition of gastric acid secretion. Famotidine ( $\mathrm{H}_{2}$-antagonist) is potent inhibitors of gastric acid secretion.

A radioimmunoassay (R1A) of secretin has been developed by several groups ${ }^{8,9}$ using ${ }^{125}$ I-secretin, and William et al. reported an assay of secretin-like immunoreactive substance (secretin-IS) in human plasma, in $1978^{10)}$. However, in terms of safety, sensitivity and easiness of handling, the existing methods are still less than satisfactory. In 1984, Tanaka et $\mathrm{al}^{11)}$. reported an enzyme immunoassay for secretin using second antibody coated silicone rods as a bound and free (B/F) separator. In the present study, we detailed a highly sensitive $(0.068$ to $2.7 \mathrm{fmol} /$ well $)$ and specific enzyme immunoassay (EIA) for human secretin using $\beta$-D-galactosidase labeled secretin (5-27) as a marker antigen, a second antibody-coated immunoplate as a B/F separator and 4-methyl-

$\dagger$ 大分県大分郡㣣間町医大ケ丘1-1；1-1, Idaigaoka, Hasama-machi, Oita, 879-5593 Japan 


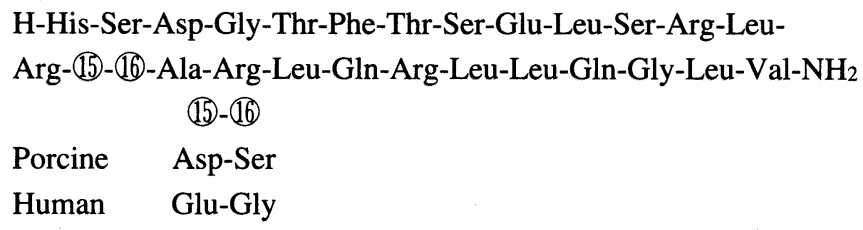

Fig. 1. Structure of Porcine and Human Secretin

umbelliferyl $\beta$-D-galactopyranoside (MUG) as a fluorogenic substrate.

\section{Materials and Methods}

\section{Materials}

Synthetic human secretin, porcine secretin, substance P (SP), gastrin 17 (Gas), cholecystokinin (CCK) and somatostatin (SS) were purchased from Peptide Institute Inc.(Osaka,Japan). Synthetic porcine secretin (5-27) was purchased from Bachem Feinchemikalien AG (Swizerland). Other synthetic peptides [vasoactive intestinal polypeptide (VIP), gastrin releasing peptide (GRP) and peptide histidine isoleucine (PHI)] were supplied from Prof. H. Yajima (Kyoto University, Kyoto,Japan).

$\beta$-D-Galactosidase ( $\beta$-gal from Escherichia coli) and goat anti-rabbit IgG (55641) were purchased from Boehringer Mannheim Corp. (Mannheim, Germany) and ICN Pharmaceuticals Inc. Cappel Products (Malvern, PA, U.S.A.), respectively.

Bovine serum albumin (BSA), polyoxyethylene sorbitan monolaurate (Tween 20), $\mathrm{N}-(\varepsilon-$ maleimidocaproyloxy) succinimide (EMC-succinimide) and 4-methyl-umbelliferyl $\beta$-D-galactopyranoside (MUG) were purchased from Sigma Chemical Co. (St. Louis, MO, USA).

An antiserum to secretin (RA-08-105) was purchased from Genosys Biotechnologies Ltd. (Cambridge. UK) and the lyophilized anti-secretinserum was reconstituted to a final volume of $100 \mathrm{ml}$ with an assay buffer $(0.05 \mathrm{M}$ phosphate buffer, $\mathrm{pH} 7.0$, containing $0.5 \% \mathrm{BSA}, 1 \mathrm{mM} \mathrm{MgCl} 2$ and 250 kallikrein inhibitor units $/ \mathrm{ml}$ aprotinin). All other chemicals were of analytical reagent grades.

\section{Preparation of Plasma Extracts}

Human plasma samples were obtained from two healthy male volunteers, aged 26 and 28 years, weighing 65 and $68 \mathrm{~kg}$. None received any medication other than placebo and famotidine during this study. Blood samples $(10 \mathrm{ml})$ were collected in a chilled tube containing 500 kallikrein inhibitor units $/ \mathrm{ml}$ aprotinin and $1.2 \mathrm{mg} / \mathrm{ml}$ EDTA. After centrifugation $\left(1670 \mathrm{~g}, 4^{\circ} \mathrm{C}, 20 \mathrm{~min}\right)$, plasma was stored at $-40^{\circ} \mathrm{C}$ until use. Human plasma $(1 \mathrm{ml})$ samples were diluted five-fold with $4 \%$ acetic acid (AcOH), $\mathrm{pH} 4.0$, and loaded on reversed-phase $\mathrm{C}_{18}$ cartridges (Sep-Pak $\mathrm{C}_{18}$ Millipore Corp., Milford, MA, U.S.A). After washing with $4 \% \mathrm{AcOH}(10 \mathrm{ml})$, the secretin-ISs were eluted with $70 \%$ acetonitrile $(\mathrm{MeCN})$ in $0.5 \% \mathrm{AcOH}, \mathrm{pH} 4.0(2 \mathrm{ml})$. Eluates were concentrated by spinvacuum evaporation, lyophilized, reconstituted to $100 \mu \mathrm{l}$ with the assay buffer and subjected to EIA. Recovery of this extraction procedure of secretin $98 \pm 6 \%$.

\section{Preparation of Enzyme-labeled Antigen, $\beta$-gal-secretin (5-27)}

Porcine secretin (5-27) was conjugated with $\beta$-gal by EMC-succinimide according to the method of Kitagawa et $\mathrm{al}^{12}$. Secretin $(5-27)(0.50 \mathrm{mg})$ was dissolved in $0.05 \mathrm{M}$ phosphate buffer, $\mathrm{pH} 7.0$ $(0.46 \mathrm{ml})$, and aliquot of tetrahydrofuran $(60 \mu \mathrm{l})$ containing EMC-succinimide $(0.50 \mathrm{mg})$ was added. 
The mixture was stirred at $20^{\circ} \mathrm{C}$ for $60 \mathrm{~min}$, then applied to a Sephadex G-25 column $(1.5 \times 50 \mathrm{~cm})$ pre-equilibrated with $0.05 \mathrm{M}$ phosphate buffer, $\mathrm{pH}$ 7.0. The column was eluted with the same buffer. Individual fractions $(1.8 \mathrm{ml}$ each) that showed absorbance at $260 \mathrm{~nm}$ were collected.The purified EMC-secretin (5-27) fractions were combined with $\beta$-gal $(7.5 \mathrm{mg})$ by mixing them at $20^{\circ} \mathrm{C}$ for $60 \mathrm{~min}$. The $\beta$-gal conjugate was then applied to a Sephacryl S-300 column $(1.5 \times 52 \mathrm{~cm})$ preequilibrated with $0.05 \mathrm{M}$ phosphate buffer $\mathrm{pH} 7.0$, containing $1 \mathrm{mM} \mathrm{MgCl}_{2}$ and was eluted with the same buffer. The fractions containing $\beta$-gal activity were collected and stored at $4{ }^{\circ} \mathrm{C}$ after addition of $0.2 \% \mathrm{BSA}$ and $0.1 \% \mathrm{NaN}_{3}$.

\section{Assay Procedure for Secretin}

For plasma samples assay, the above-mentioned assay buffer was used. Secondary-antibodycoated immunoplates were prepared as previously reported using Microwell MaxiSorp F 8 plates (Nunc, Roskilde, Denmark) and anti-rabbit $\mathrm{IgG}^{13}$. A test tube containing $100 \mu \mathrm{l}$ of secretinantiserum, RA-08-105 and each sample (or standard) of $100 \mu \mathrm{l}$ were mixed and incubated at $4^{\circ} \mathrm{C}$ for $24 \mathrm{~h}$. And then, diluted enzyme-labeled antigen (Secretin (5-27)- $\beta$-gal, $50 \mu \mathrm{l}$ ) was added. The test tube was incubated at $4^{\circ} \mathrm{C}$ for additional $24 \mathrm{~h}$. The antigen-antibody solution $(100 \mu \mathrm{l})$ from each sample tube was added to the secondary antibody-coated immunoplate. The plate was incubated at $4^{\circ} \mathrm{C}$ for overnight, washed 4 times with a washing buffer $(0.01 \mathrm{M}$ phosphate buffer, $\mathrm{pH}$ 7.0 , containing $0.15 \mathrm{M} \mathrm{NaCl}$ and $0.05 \%$ Tween 20 ), and then $0.1 \mathrm{mM} \mathrm{MUG}(200 \mu \mathrm{l})$ in a substrate buffer $\left(0.05 \mathrm{M}\right.$ phosphate buffer, $\mathrm{pH} 7.0$, containing $1 \mathrm{mM} \mathrm{MgCl}_{2}$ ) was added to each well. The plate was again incubated at $37^{\circ} \mathrm{C}$ for $3 \mathrm{~h}$. The resulting fluorescence intensity $\left(\lambda_{\mathrm{Ex}} 360 \mathrm{~nm} \lambda_{\mathrm{Em}} 450\right.$ $\mathrm{nm}$ ) of each well was measured with a MTP-1 $00 \mathrm{~F}$ microplate reader (Corona Electric, Ibaraki, Japan).

\section{HPLC of Plasma Extracts}

HPLC was performed using a reversed-phase $\mathrm{C}_{18}$ column (Cosmosil $5 \mathrm{C} 18 \mathrm{AR}$, Nacalai Tesque, Kyoto, Japan). The HPLC consisted of a model 610 dual pump system (Millipore Corp., Milford, MA, U.S.A.). The plasma samples $(1 \mathrm{ml})$, purified by the Sep-Pak $\mathrm{C}_{18}$ cartridge mentioned above, were reconstituted to $100 \mu \mathrm{l}$ with $0.1 \%$ trifluoroacetic acid (TFA) and passed through the column. Secretin-ISs were eluted with a linear gradient of $\mathrm{MeCN}$ (from 5\% to $50 \%$ over $45 \mathrm{~min}$ ) in $0.1 \%$ TFA. The flow rate was $1 \mathrm{ml} / \mathrm{min}$ and the fraction size was $1 \mathrm{ml}$. Collected fractions were concentrated by spin-vacuum evaporation, lyophilized, and reconstituted to $100 \mu \mathrm{l}$ with the assay buffer prior to undergoing EIA.

\section{Results}

\section{Standard Curve}

A typical calibration curves for the secretin-EIA are shown (Fig. 2 ). A linear displacement of enzyme-labeled secretin (5-27) by synthetic secretin was obtained, when the data were plotted as a semi-logarithmic function, between 0.67 and $330 \mathrm{fmol} / \mathrm{ml}$. The minimum amount of secretin detectable by this EIA system was $1.7 \mathrm{fmol} / \mathrm{ml}(0.068 \mathrm{fmol} /$ well $)$, approximately the same sensitivity as obtained using the RIA methods ${ }^{8,9}$. The coefficients of variation for within-and between-assay were $5 \%$ and $11 \%$ respectivery.

\section{Specificity of the Antiserum (RA-08-105) Examined by EIA}

Immunospecificity of the antiserum (RA-08-105) was examined by EIA using secretin (5-27)- $\beta$ - 


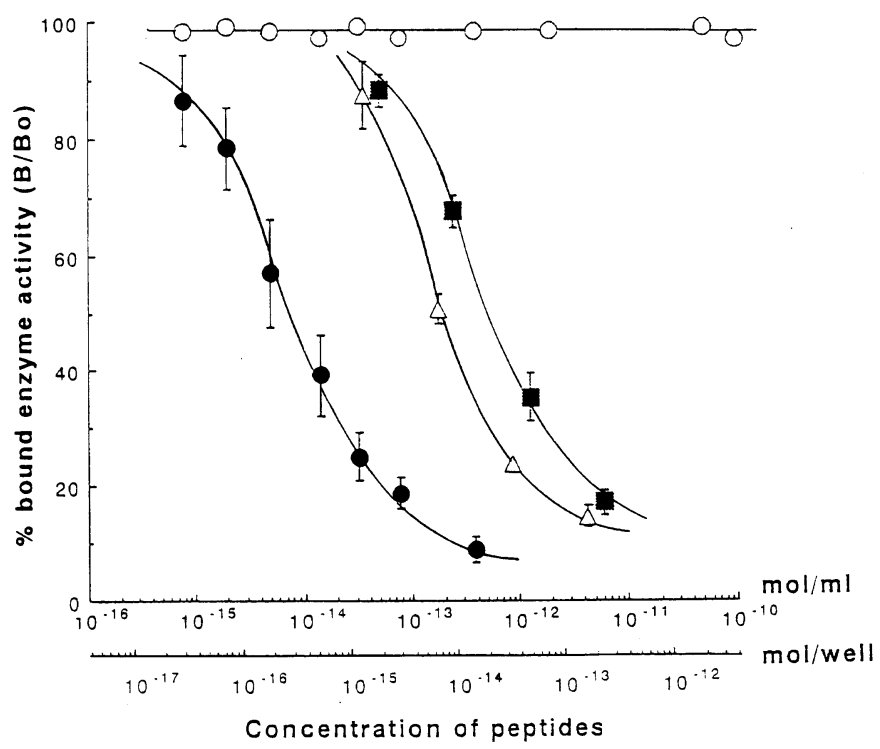

Fig. 2. Competitive Inhibition of Secretin and Various Peptides in the EIA

Each vertical bar represents the standard deviation. $(n=6)$

: human secretin, $\triangle$ : porcine secretin, $\mathbf{\square}$ : porine secretin (5-27),

: peptides (SP, GRP, PHI, VIP, somatostatin, gastrin, CCK)

gal. The displacement curves of secretin-related peptides and other endogenous peptides are shown (Fig.2). Porcine secretin and the carboxy-terminal fragment (5-27) exhibited reduced crossreactivity (approximately $1 \sim 5 \%$ ). SP, GRP, PHI, VIP, SS, Gas and CCK minimally inhibited the binding of secretin (5-27)- $\beta$-gal with the secretin-antibody. Thus, the secretin-antiserum, RA-08105 , recognizes the human secretin and can distinguish secretin from other endogenous peptides.

\section{HPLC of Human Plasma Extracts}

Human plasma extracts were subjected to reversed phase HPLC to assess the molecular variants of secretin-ISs present in human plasma. Extracts from human plasma $(1 \mathrm{ml})$ using a Sep-Pak $\mathrm{C}_{18}$ cartridge were applied to reversed phase HPLC on a $\mathrm{C}_{18}$ column. The elution profiles revealed the presence of two immunoreactive peaks (Fig. 3 ). One was eluted at the position corresponding to that of standard human secretin, with small peak eluted earlier.

\section{Measurements of Secretin-IS in Human Plasma by EIA}

The proposed EIA was applied to the determination of secretin-IS in human plasma. Concentrations of secretin-IS in plasma were measured before and after administration of famotidine in two healthy male volunteers. In this study, famotidine and placebo were administered two hours after lunch. The significant changes in plasma secretin-IS levels were found after an oral administration of famotidine (vs.placebo) (Fig. 4 ).

\section{Discussion}

The instability of secretin in aqueous solution is a well documented phenomenon ${ }^{14)}$. Apparent autolysis of the N-terminal tetrapeptide, His-Ser-Asp-Gly, was reported ${ }^{15}$. Thus, we used stable porcine secretin (5-27) as a marker antigen. Using $\beta$-gal-labeled secretin (5-27) as a marker antigen, 


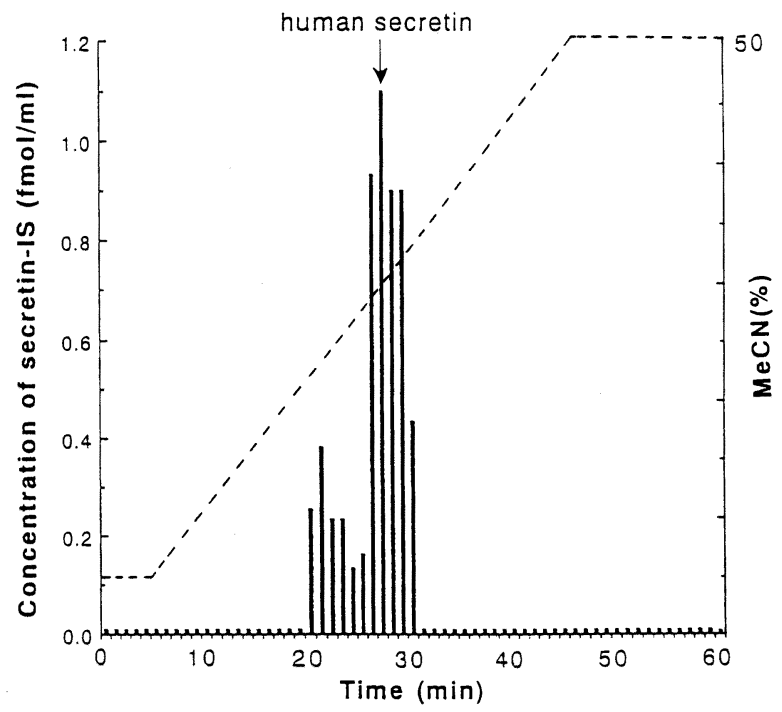

Fig. 3. HPLC Elution Profiles of Plasma Extracts

Secretin-ISs extracted from plasma $(1 \mathrm{ml})$ samples by Sep-Pak $\mathrm{C}_{18}$ cartridge were dissolved in $0.1 \%$ TFA and passed through an HPLC column. The MeCN gradient is indicated by the straight line. Fractions were lyophilized and the secretin-IS content of each fraction was measured. Synthetic secretin was run in separate chromatographs under the same condition and the fraction containing this compound is indicated by the arrow. Column, Cosmosil 5 C 18 AR (4.6x $150 \mathrm{~mm}$ ) ; flow rate, $1 \mathrm{ml} / \mathrm{min}$; fraction volulme, $1 \mathrm{ml}$.

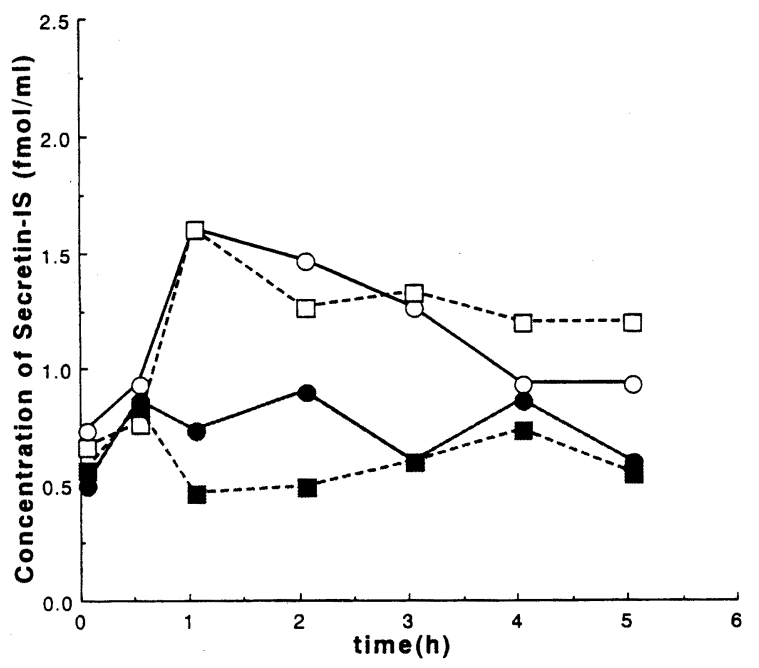

Fig. 4. Time Course of Secretin-IS Levels after an Oral Administration of Famotidine or Placebo $(\mathrm{n}=2)$ Subject 1 (Placebo $1 ; \bigcirc$, Famotidine $1 ; 0$ ), Subject 2 (Placebo $2 ; \square$ Famotidine $2 ; \square$ ) 
an anti-rabbit $\lg$ coated immunoplate as a bound/free (B/F) separator and MUG as a fluorogenic substrate, we developed a highly sensitive and specific and specific EIA for EIA for the quantification of secretin. Since 1973, RIA methods developed for secretin have been widely used ${ }^{8,9}$, and in 1978 Chey et $\mathrm{al}^{10)}$. reported an assay of secretin in human plasma. However these methods have several disadvantages with the use of radioisotopes. In 1984, Tanaka et al.reported an EIA for secr etin using silicone rods, the minimum detectable amount of secretin was $2.5 \mathrm{pg} /$ assay $(0.83 \mathrm{fmol} /$ $\mathrm{ml}$ ) using porcine secretin (18-27)- $\beta$-gal. The EIA for secretin retain the advantage of the RIA system and minimize these disadvantages, but an assay procedure using second-antibody coated silicon rods was somewhat troublesome. The present EIA for human secretin reported here, using a second antibody-coated immunoplate as a B/F separator, is simple and handling is quite easy. Furthermore, the sensitivity of our EIA was higher [204 fg/assay $(0.068 \mathrm{fmol} /$ assay $)]$ than the method of Tanaka. In addition, this EIA was specific for quantification of secretin and a sharp standard inhibition curve was obtained.The calibration curve was linear in the range of 1.7 to $67 \mathrm{fmol} / \mathrm{ml}$.

We applied the present assay system to the determination secretin-IS in human plasma. Using the extraction procedure with a Sep-Pak $\mathrm{C}_{18}$ cartridge from human plasma combined with this EIA, a secretin-IS Ievels determined. Then we examined change of secretin-IS levels in plasma after an oral administration of famotidine or placebo. Thus, the significant changes in plasma secretin-IS levels were found, after an oral administration of) famotidine (vs. placebo) ${ }^{10,16)}$.

In this study, we identified the presence of immunoreactive secretin in human plasma extract. The major peak of secretin-IS in human plasma was eluted at an identical position with standard synthetic human secretin, with a minor peak eluted earlier.

Thus, this simple and sensitive EIA will be useful for the measurement of human secretin in biological fluids and tissues.

\section{References}

1) J. E. Jorpes and V. Mutt, Acta Chem. Scand., 15, 1790-1971 (1961).

2) W.M. Bayliss and E.H. Starling, J. Physiol., 28, 325-353 (1902).

3) V. Mutt, J.E. Jorpes and S. Magnusson, Eur. J. Biochem., 15, 513-519 (1970).

4) M. Carlquist, H. Jornvall and V. Mutt, FEBS Lett., 127, 71-74 (1981).

5) M. Carlquist, H. Jornvall, W.G. Forssmann, L. Thulin, C. Johansson and V. Mutt, IRCS Med. Sci., 13, 217-218 (1985).

6) D. Grossen, A. Vandermeers, M. Vandermeers-Piret, J. Rathe, A. Cauvin, P. Robberecht and J. Christophe, Biochem. Biophys. Res. Commun., 160, 862-867 (1989).

7) A. Nillson, M. Carlquist, H. Jornvall and V. Mutt, Eur. J. Biochem., 112, 383-388 (1980).

8) G. Boden and W.Y. Chey; Endocrinology, 92, 1617-1624 (1973).

9) T. Chang and W.Y. Chey, Gastrointestinal Hormones, 34, 797-806 (1980).

10) W.Y. Chey, H.Lee, J.G. Hendricks, R.A. Rhodes and H.H. Tai, Am. J. Dig. Dis., 23, 981-988 (1978).

11) H. Tanaka and K. Katayama, Anal. Biochem., 139, 190-196 (1984).

12) K. Kitagawa, T. Shimozono, T. Aikawa, T. Yoshida and H. Nakamura, Chem. Pharm. Bull., 29, 11301135 (1981).

13) M. Takeyama, K. Kondo, Y. Hayashi and H. Yajima, Int. J. Pept. Prot. Res., 34, 70 (1989).

14) M. Bodanszky, M.A. Ondetti, S.D. Levine and N.J. Williams, J. Am. Chem. Soc., 89, 6753 (1967). 
15) S. Kiyama, K. Kitagawa, T. Akita, W.Y. Chey, A. Ayalp, A. Otsuki, S. Funakoshi, N. Fujii and H. Yajima, Chem. Pharm. Bull. 33, 3205-3217 (1985).

16) W.Y. Chey, T.M. Chang, K.Y. Lee, J. Rominger, R.A. Rhods and C.H. You, Gut Hormones., 213-219 (1981). 